percentage of the total number published that are entered in the Bibliography, and this percentage obviously depends on the number of contributors. In the absence of collaborators, memoirs are, of course, likely to be overlooked.

\section{World Power Conference}

THE annual report for 1934 of the World Power Conference, 36 Kingsway, London, W.C.2, records that the transactions of the Scandinavian meeting held in 1933 have been published in seven volumes. The subjects discussed centre round the power problems of large-scale industry and of land and sea transport. The Chemical Engineering Congress will be held in London on June 22-27, 1936, and will be a sectional meeting of the World Power Conference. After preparatory work extending over seven years, it is hoped that tables of international statistics on a strictly comparative basis will be published this year.

\section{Conference of Empire Survey Officers}

ThE Third Conference of Empire Survey Officers opened in London on July 23 and will continue in session until August 2. The Conference is not open to the public, but an official report of its proceedings will be published in due course. Representatives of Canada, the Commonwealth of Australia, the Union of South Afriea, the Irish Free State, India and Northern Ireland, and of about twenty Colonial dependencies, as well as by representatives of various interested departments, societies and institutions in Great Britain, are attending the Conference. The principal object of these gatherings, of which the two earlier ones were held in 1928 and 1931 respectively, is to afford opportunities for surveyors from overseas to obtain and exchange up-to-date information as to the progress made in survey matters, and for discussions on questions of general interest to surveyors.

IN opening the Empire Survey Conference on July 23, Mr. Malcolm MacDonald, the Secretary of State for the Colonies, expressed his pleasure at being able to welcome at the Conference not only representatives of the various Colonies, Protectorates and Mandated Territories, but also representatives of the majority of the self-governing Dominions, of India, and of Northern Ireland. He referred to some of the subjects to be discussed, such, for example, as trigonometrical and topographical surveying, and various aspects of air survey work. Continuing, Mr. MacDonald said, "Another question which appears on your agenda is that of the co-ordination of African surveys. I need hardly emphasise the importance of this, but I should like to express the hope that this Conference will be able to work out an agreed plan for co-ordination in the future. Closely allied with this is the question of the completion of the Arc of the 30th meridian. The possibility of completing this important work at the earliest possible moment is kept continually in mind." Brigadier MacLeod, the Director General of the Ordnance Survey, who was asked by Mr. MacDonald to preside over the Conference, then thanked the Secretary of State on behalf of the delegates for coming to open the
Conference and emphasised the value of periodical Conferences of this nature.

\section{ASLIB}

THE twelfth annual conference of the Association of Special Libraries and Information Bureaux is to be held on September 20-23 at St. John's College, Cambridge. According to the preliminary programme, Sir Richard Gregory will deliver his presidential address on September 20 and will speak on the "Interpretation of Science". Mr. J. D. Cowley, director of the University of London School of Librarianship, and others will deal in a symposium with special librarians and their problems, Sir Stephen Gaselee, of the Foreign Office Library, will describe libraries and special sources of information in Government departments, and Mr. B. M. Headicar, of the British Library of Political and Economic Science, will deal with the use of reference books. "What Industry expects from Public Libraries" is the title of a paper by Mr. R. Brightman, of Imperial Chemical Industries, Ltd., while Miss E. W. Parker, of the Mond Nickel Co., Ltd., inquires into the use that industry and commerce make of the public libraries in the London area. Further particulars about the meeting can be obtained from the Secretary, ASLIB, 16 Russell Square, London, W.C.1.

\section{The Third International Congress of Soil Science}

Some four hundred delegates, from twenty-five foreign and twenty British countries, will assemble at Oxford for the Third International Congress of Soil Science on July 30-August 7. The delegates will be welcomed by the Vice-Chancellor of the University at the opening session, and will be entertained by the Government at a dinner in Christ Church Hall on July 31. The meetings have been arranged so that questions of wide interest will be discussed in the mornings at plenary sessions, and more specialised ones in the afternoons at Commission sessions. Sir John Russell will deliver the presidential address on "The Place of Soil Science in Agriculture", and Prof. G. W. Robinson will present a general survey of British soils. The plenary session of Commission IV -Soil Fertility - promises to be of particular interest. Prof. E. A. Mitscherlich will describe the co-operative work developed and organised by him in Germany to test his physiological methods of determining fertility, Prof. R. A. Fisher will outline the principles of his well-known methods of field experimentation as used in England, and Prof. O. de Vries will deseribe fertility measurements in the tropics with special reference to work in the Netherlands Indies. Other papers likely to attract attention are by Prof, F. Hardy on tropical soil types, by Dr. Brüne on the cultivation of moorland, and by Prof. Lowdermilk on the measures now being adopted in the United States for the control of soil erosion. The programme covers the whole field of pure and applied soil science, and includes a number of excursions of both scientific and scenic interest in the neighbourhood of Oxford.

\section{Beit Fellowships for Scientific Research}

THE Trustees of the Beit Fellowships have awarded the following fellowships for research at the Imperial 